\title{
IDENTIFICATION OF STAPHYLOCOCCUS AUREUS, S. INTERMEDIUS AND S. HYICUS BY PCR AMPLIFICATION OF COA AND NUC GENES
}

\section{Wladimir Padilha da Silva ${ }^{1 *}$; Jorge Adolfo Silva²; ${ }^{2}$ Márcia Raquel Pegoraro de Macedo ${ }^{1}$; Márcia Ribeiro de Araújo ${ }^{1}$; Márcia Magalhães Mata ${ }^{1}$; Eliezer Avila Gandra ${ }^{1}$}

${ }^{1}$ Laboratório de Microbiologia de Alimentos, Departamento de Ciências e Tecnologia Agro-industrial, Faculdade de Agronomia Eliseu Maciel, Universidade Federal de Pelotas, Pelotas, RS, Brasil.

${ }^{2}$ Laboratório de Biotecnologia de Alimentos, Departamento de Ciências e Tecnologia Agro-industrial, Faculdade de Agronomia Eliseu Maciel, Universidade Federal de Pelotas, Pelotas, RS, Brasil.

This paper corresponds to an "extended abstract" selected for oral presentation in the $22^{\text {nd }}$ Brazilian Congress of Microbiology, held in Florianópolis, SC, Brazil, in November 17-20, 2003

\begin{abstract}
Sixty-five strains of coagulase positive staphylococci (Staphylococcus aureus, S. intermedius and S. hyicus) were identified at species level by PCR amplification of the coa gene, specific for $S$. aureus, and of the nuc gene, specific for $S$. intermedius and for $S$. hyicus.
\end{abstract}

Key words: coagulase positive staphylococci, PCR, coa gene, nuc gene.

\section{INTRODUCTION}

S. aureus, S. hyicus and S. intermedius are species of staphylococcus associated with food intoxication outbreaks (5) that present very similar phenotypic characteristics, which makes the identification and differentiation through traditional culture techniques defficult (5,7). Despite the recommendation for the use of methods based on the polymerase chain reaction (PCR) to select pathogens among other bacterial species (2), very limited research using molecular methods to differentiate $S$. aureus, $S$. hyicus and $S$. intermedius has been reported. This work ained to evaluate the amplification of the gene sequences of coa and nuc for the identification of S. aureus, S. intermedius and S. hyicus.

\section{MATERIALS AND METHODS}

Sixty-five strains previously characterized as coagulase positive staphylococci (CPS) and identified as S. aureus (55 strains), S. intermedius (4 strains) and S. hyicus (6 strains) were used. The genomic DNA extraction from all strains was done according to the protocol proposed by Matthews et al. (6). The primers used in the PCR were: COAG2 and COAG3, specific for the coa gene of $S$. aureus; NUC1 and NUC2, specific for the nuc gene of $S$. intermedius and NUC3 and NUC4, specific for the nuc gene of $S$. intermedius (Table 1).

The PCR reactions were prepared with $20 \mathrm{nM}$ of extracted DNA, $1 \mu \mathrm{M}$ of each primer, $200 \mu \mathrm{M}$ of each triphosphate desoxinucleotide (dNTP, Gibco BRL), $1 \mathrm{U}$ of Taq DNA Polymerase (Pharmacia, 5 U. $\mu \mathrm{L}^{-1}$ ), $2 \mathrm{mM}$ of $\mathrm{MgCl}_{2}$ (Pharmacia) and $4 \mu \mathrm{L}$ of $10 \mathrm{X}$ buffer (Pharmacia), making a total volume of 40 $\mu \mathrm{L}$. The program consisted of 50 seconds at $95^{\circ} \mathrm{C}, 2$ minutes at $55^{\circ} \mathrm{C}$ (for primers $\mathrm{COAG}$ ) or at $42^{\circ} \mathrm{C}$ (for primers NUC) and 4 minutes at $72^{\circ} \mathrm{C}$, for 40 cycles (4). The electrophoresis was performed in agarose gel $(\mathrm{p} / \mathrm{v})$ stained with $0.5 \mathrm{mg} \cdot \mathrm{mL}^{-1}$ of ethidium bromide. The size of the amplified fragments was determined under UV light, through comparison with the molecular weight standard (1 Kb Plus DNA Ladder or 100 bp DNALadder, Gibco BRL).

*Corresponding author. Mailing address: Laboratório de Microbiologia de Alimentos, Departamento de Ciências e Tecnologia Agro-industrial, Faculdade de Agronomia Eliseu Maciel, Universidade Federal de Pelotas, Campus Universitário s/n, Caixa Postal 374. 96010-900, Pelotas, RS, Brasil. Fax: (+5553) 2759031. E-mail: silvawp@ufpel.tche.br 
Table 1. Oligonucleotide used for molecular identification and differentiation among S. aureus, S. intermedius and S. hyicus, PCR products and target species.

\begin{tabular}{|c|c|c|c|}
\hline Primer & Sequence $5^{\prime}-3^{\prime}$ & $\begin{array}{c}\text { Estimated amplification } \\
\text { product }(\mathrm{pb})\end{array}$ & Species \\
\hline $\mathrm{NUC1}^{\mathrm{a}}$ & GCCCCTGCAATGAGAGG & \multirow{2}{*}{334} & \multirow{2}{*}{ S. hyicus } \\
\hline $\mathrm{NUC2} 2^{\mathrm{a}}$ & CGGACCACTTTCCGTC & & \\
\hline $\mathrm{NUC}^{\mathrm{a}}$ & CGCCGTTCTCTCTTTGG & \multirow{2}{*}{431} & \multirow{2}{*}{ S. intermedius } \\
\hline $\mathrm{NUC4} 4^{\mathrm{a}}$ & CGCCTCTCACATCCG & & \\
\hline $\mathrm{COAG}^{\mathrm{b}}$ & ACCACAAGGTACTGAATCAACG & Variable & S. aureus \\
\hline
\end{tabular}

${ }^{a}$ Design from the complete sequence of nuc, obtained from GenBank/NCBI (Accession number L23973 for S. hyicus and X67678

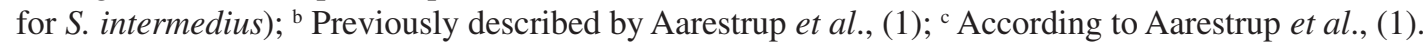
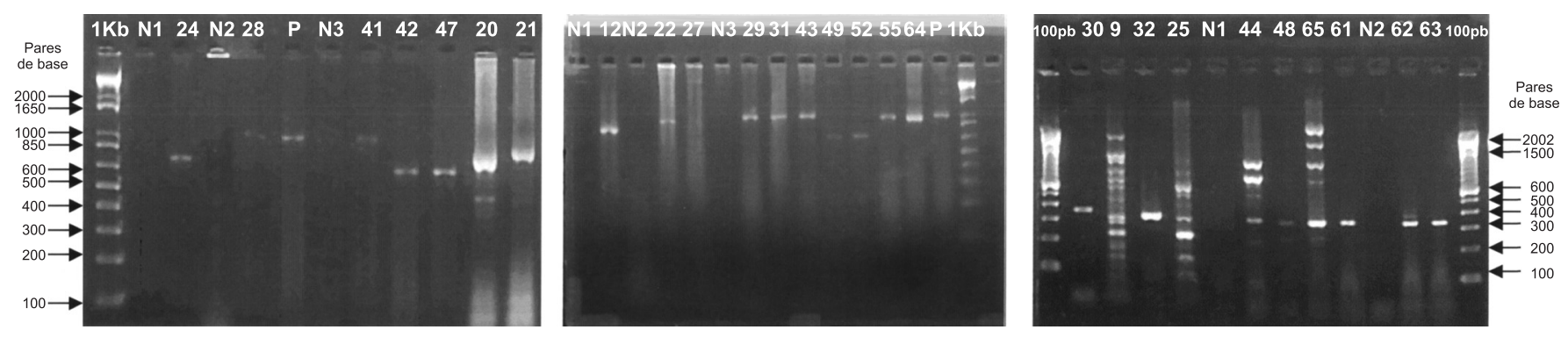

Figure 1. Agarose gel 1\%, stained with ethidium bromide, under ultraviolet light. A - 1 kb - Plus DNA Ladder, N1 - sterile distilled water, N2 - S. intermedius, N3 - S. hyicus, P - S. aureus ATCC 10832. B - 1 kb-Plus DNA Ladder, N1- sterile distilled water, N2 - S. intermedius, N3 - S. hyicus, P - S. aureus ATCC 10832. C - 100 bp - DNA Ladder, N1- sterile distilled water, N2- S. aureus ATCC 10832. 12, 22, 20, 21, 24, 27, 28, 29, 31, 41, 42, 43, 47, 49, 52, 55 and 64 are PCR products obtained with cultures of S. aureus. 30, 32, 48, 61, 62 and 63 are PCR products obtained with cultures of S. hyicus and 9, 25, 44 and 65 are PCR products from cultures of $S$. intermedius. A and B amplifications with COAG2-COAG3 primers, C amplifications with NUC1-NUC2 and NUC 3-NUC4 primers.

\section{RESULTS AND DISCUSSION}

It was verified that $\mathrm{COAG} 2$ and COAG3 primers showed specificity for $S$. aureus, as amplifications were obtained in all the reactions in which DNA from this species (3) was used (Fig. 1). These results are in accordance with Aarestrup et al. (1), who studied the amplification of sequences of the coa gene in 187 strains of $S$. aureus, 10 strains of S. intermedius, 3 strains of $S$. hyicus, 1 strain of $S$. delphini and 1 strain of $S$. schleiferi subspecies coagulans and verified the presence of bands only in $S$. aureus. The variability in the size of the amplified fragments with primers COAG2 e COAG3 may be due to the existence of structurally different gene forms of coagulase in S. aureus, allowing one strain to produce one or more of these variants (4). However, the reason for this polymorphism is not clear yet (4).

NUC1 and NUC2 primers demonstrated to be specific for $S$. hyicus, as there was amplification only when the DNA from this microorganism was used (Fig. 1). Although these results refer only six strains of S. hyicus, the observed specificity indicates that these primers have potential to be used in the differentiation between this species and S. aureus and S. intermedius.

A great variability in the size of the amplified fragments obtained with NUC3 and NUC4 primers was verified. However, the expected fragment (431 bp) was always obtained when the DNA from $S$. Intermedius was submitted to amplification (Fig. 1). This polymorphism may be related to the conditions used for the PCR, which could be enabling unspecific amplifications or, also allowing the primers to attach to other genes with similar sequences or partially homologous. Despite the small number of strains tested, these results showed that these primers have potential to be used in CPS identification and differentiation studies, but conditions of the reaction still need to be optimized.

\section{ACKNOWLEDGEMENT}

This work was supported by Capes and CNPq/Pibic schoolarship. 


\section{RESUMO}

\section{Identificação de Staphylococcus aureus, S. intermedius e $S$. hyicus através de seqüências dos genes coa e nuc.}

Sessenta e cinco cepas de estafilococos coagulase positiva foram identificadas em nível de espécie, através da amplificação, por PCR, de seqüências do gene coa, específicas para S. aureus, e do gene nuc, específicas para S. intermedius e para S. hyicus.

Palavras-chave: estafilococos coagulase positiva, PCR, gene coa, gene nuc.

\section{REFERENCES}

1. Aarestrup, F.M.; Wegener, H.C.; Rosdahl, V.T. Evaluation of phenotypic and genotypic methods for epidemiological typing of Staphylococcus aureus isolates from bovine mastitis in Denmark Vet. Microbiol., 45:139-150, 1995.
2. Farber, J.M.; Gendel, S.M.; Tyler, K.D.; Boerlin, P.; Landry, W.L.; Fritschel, S.J.; Barrett, T.J. Molecular typing and differentiation. In: Compendium of methods for the microbiological examination of foods. APHA, Washington, 2001. p.127-158.

3. Gandra, E.A. Identificação de Staphylococcus aureus, S. hyicus $e \mathrm{~S}$. intermedius através de testes bioquímicos e da amplificação por $P C R$ de sequências dos genes coa $e$ nuc. (Dissertação de mestrado, Universidade Federal de Pelotas). Pelotas, 2003, p.101.

4. Goh, S.H.; Byrne, S.K.; Zhang, J.L.; Chow, A.W. Molecular typing of Staphylococcus on the basis of coagulase gene polymorphism. J. Clin. Microbiol., 30:1642-1645, 1992.

5. Kloos, W.E.; Bannerman, T.L. Staphylococcus and Micrococcus In: Murray, P.R.; Baron, E.J.; Pfaller, M.A.; Tenover, F.C.; Yolken, R.H. Manual of Clinical Microbiology. ASM, Washington, 1999. p.264-282.

6. Matthews, K.R.; Roberson, J.; Gillespie, B.E.; Luther, D.A.; Oliver, S.P. Identificação and differentiation of coagulase-negative Staphylococcus aureus by polymerase chain reaction. J. Food Prot., 60:686-688, 1997.

7. Roberson, J.R.; Fox, L.K.; Hancock, D.D.; Besser, T.E. Evaluation of methods for differentiation of coagulase-positive Staphylococci. J. Clin. Microbiol., 30:3217-3219, 1992 